19. Гапочка С.Н., Крючков М.А., Сурков А.В. Периодизация неолита, энеолита лесостепного Дона в трудах А.Т. Синюка // Проблемы археологии Восточной Европы в работах профессора А.Т. Синюка (к изданию «Избранных трудов»). Воронеж: Воронежский государственный педагогический университет, 2016. C. 52-55.

20. Смольянинов Р.В., Куличков А.А., Юркина Е.С. Стоянка среднедонской культуры Доброе 9 на Верхнем Дону // XXI Уральское археологическое совещание, посв. 85-летию со дня рожд. Г.И. Матвеевой и 70-летию со дня рожд. И.Б. Васильева. Самара: Издво СГСПУ; ООО «Порто-принт», 2018. С. 67-71.
21. Синюк А.Т. Стоянка Монастырская-І как источник для выделения мезолита и периодизации неолита на Среднем Дону // Избранные труды. Воронеж: Воронежский государственный педагогический университет, 2015. С. 261-272.

22. Скоробогатов А.М. Энеолитические памятник Донской лесостепи: автореф. дис. ... канд. ист. наук. Воронеж, 2011.23 c.

23. Васильева И.Н. К вопросу о гончарных традициях неолитического населения Подонья // Известия Самарского научного центра Российской академии наук. 2017. Т. 19, № 3 (2). С. 370-379.

Исследование выполнено за сиет гранта Российского научного фонда (проект № 17-78-20048).

\title{
MIDDLE-DON NEOLITHIC CULTURE: PROBLEMS OF SELECTION, CHRONOLOGY AND PERIODIZATION
}

(C) 2019

Surkov Aleksey Vladimirovich, candidate of historical sciences, archaeologist

Center for Security Archaeological Research (Voronezh, Russian Federation)

Abstract. The paper deals with the main results of the Middle-Don Neolithic culture study. The contribution of A.T. Sinyuk is noted. The paper also contains some evolution of his views on the content of the early stage of the culture. So, the first periodization, done in 1971 as a result of Universitetskaya III site study, was then adjusted, especially after the excavations of Monastyrskaya I site. The culture chronology according to modern concepts fits into the IV-V millennium BC. The origin of the Middle-Don culture is debatable. New absolute dating allows us to consider the early stage in the first half of the VI - third quarter of the VI millennium BC and associate it with the first monuments with stroke ceramics and plate stone inventory. The author notes that there was an interaction of the Middle Don population with the Karamyshevsky population at the early stage. During the last quarter of the VI first quarter of $\mathrm{V}$ millennium $\mathrm{BC}$ stroke-ornamented-comb ware spread, ornament completely filled the outer surface of the vessels. Late stage - second quarter $\mathrm{V}-$ end $\mathrm{V}$ millennium BC, the syncretic types were formed. Vestigial stage - the beginning of IV millennium BC, there was an end of Middle-Don traditions, they were rare in the Rybnoozersky type of ceramics.

Keywords: Neolithic; archaeological culture; periodisation; chronology; forest-steppe Don; Voronezh river; Pobituzhie; Universitetskaya III site; Monastyrskaya I site; Dobroe 9 site; Vasilievsky cordon 7 site; ceramics; ornamentation; stroke; Karamyshevskaya culture; Middle-Don culture.

УДК 903.4

DOI 10.24411/2309-4370-2019-12222

Статья поступила в редакцию 16.02.2019

\section{ПЕРЕСМОТР МАТЕРИАЛОВ ПОСЕЛЕНИЯ КАМЕННОГО ВЕКА РИЙГИКЮЛА І (ЭСТОНИЯ)}

(C) 2019

Хрусталева Ирина Юрьевна, докторант кафедры лабораторной археологии;

младший научный сотрудник отдела археологии Восточной Европы и Сибири

Тартуский университет (2. Тарту, Эстонская Республика); Государственный Эрмитаж

(2. Санкт-Петербург, Российская Федерация)

Крийска Айвар, доктор, профессор кафедры лабораторной археологии

Тартуский университет (2. Тарту, Эстонская Республика)

Холкина Маргарита Алексеевна, кандидат исторических наук,

старший преподаватель кафедры археологии; инженер отдела региональной геоэкологии и морской геологии

Санкт-Петербургский государственный университет (2. Санкт-Петербург, Российская Федерация);

Всероссийский научно-исследовательский геологический институт им. А.П. Карпинского

(2. Санкт-Петербург, Российская Федераиия)

Аннотация. Памятник Рийгикюла I на северо-западе Эстонии, открытый и исследованный в начале 1950х гг., является важным источником информации о быте и хозяйстве населения каменного века Прибалтики и одним из немногих поселений в Эстонии с остатками жилищ. Помимо двух углубленных построек здесь было найдено несколько очагов, два целых человеческих скелета и отдельные человеческие кости, а также богатый инвентарь, представленный обломками глиняных сосудов, изделиями и отходами производства из кварца, кости, рога, кремня и пр. Первоначально памятник был интерпретирован как одно долговременное поселение. Однако появлявшиеся новые данные по другим памятникам региона, а также частичный повторный анализ глиняной посуды и полученные AMS датировки по человеческим костям показали необходимость пересмотра всех материалов. Предварительные результаты этих работ представлены в нашей статье. Было установлено, что на поселении существовало как минимум четыре постройки, соотносимые с материалами культур нарвской и гребенчатой керамики, что указывает на то, что, по крайней мере, частично они бы- 
ли разновременны. Находки в культурном слое, очевидно, перемешаны по вертикали ввиду разновременных заселений этого участка, но планиграфически они имеют четкую привязку к объектам. В какой-то период это место, по-видимому, посещалось носителями культуры шнуровой керамики (судя по немногочисленным фрагментам посуды). А уже в середине бронзового века люди пришли сюда хоронить своих покойников.

Ключевые слова: каменный век; эпоха бронзы; побережье Балтийского моря; северо-восточная Эстония; бассейн р. Нарвы; поселение каменного века; многослойное поселение; гребенчатая керамика; нарвская керамика; углубленные жилища; остатки построек; очаги; погребения бронзового века; стратиграфия; планиграфический анализ.

\section{Введение}

Отдельные находки изделий каменного века в бассейне реки Нарвы, в настоящее время пограничной территории Эстонии и России, были собраны уже в конце XIX - начале XX вв. [1, с. 359]. В 1930-х гг. началось планомерное изучение этой территории, в результате чего были открыты местонахождения костяных предметов и рыболовной сети, а также несколько поселений (Ломми I-III), на которых проводились раскопки [2; 3, lk. 30; 4, 1k. 5; 5; 6, s. 94]. Но первые масштабные археологические исследования здесь связаны с именем Нины Николаевны Гуриной, руководившей специально созданной в 1951 г. Нарвской археологической экспедицией Ленинградского отделения Института истории материальной культуры для работ в зоне планируемого затопления территории в результате строительства Нарвской ГЭС.

Направляясь на известное по находкам предметов каменного века местонахождение Тырвала, расположенное на правом берегу р. Нарвы, в 7 км к северозападу от г. Нарвы, в ожидании переправы на левом берегу реки, Н.Н. Гурина осмотрела дюны на территории бывшей деревни Рийгикюла, прилегающие к дороге, связавшей города Нарва и Нарва-Йыэсуу [7, л. 2-3]. В ходе осмотра были выявлены участки нарушенного культурного слоя - темного песка, содержавшие фрагменты керамики, каменные и костяные изделия. В результате были открыты три памятника каменного века, получившие названия Нарва IIII (Нарва-Рийгикюла I-III или Рийгикюла I-III, далее в тексте - Рийгикюла) [8], территория которых, несмотря на то что не входила, собственно, в зону затопления, была раскопана в 1951-1953 гг. Н.Н. Гуриной широкой площадью [9-11]. В ходе раскопок был выявлен богатый набор глиняных, каменных, костяных и роговых изделий, а также остатки разнообразных поселенческих и погребальных объектов.

Последующие работы в районе Нарвы, точнее в Нарвско-Лужском междуречье, продолжались с перерывами с конца $1950-$ х гг. [12; 13, с. 91-99; 14, с. $410-412 ; 15$, с. $122-123 ; 16 ; 17]$ и особенно активно ведутся несколько последних десятилетий [18; 19 ; $20 ; 21 ; 22]$. В общей сложности открыты и исследованы, в том числе раскопками, десятки разновременных поселений каменного века (рис. 1: Б), связанных с побережьем Финского залива, а также реками и ручьями, впадающими в него. На территории бывшей деревни Рийгикюла на данный момент известно 15 памятников (рис. 1: $B$ ), на части из которых были проведены раскопки [23; 24; 25; 26; 27].

Но исследования начала 1950 -х гг. не утратили своей научной значимости. Среди памятников, раскопанных Нарвской экспедицией, наиболее представительна стоянка Рийгикюла І. Общая площадь раскопа Н.Н. Гуриной на этом памятнике составила

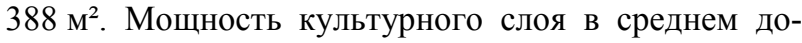

стигала 0,8 м, а максимально - 1,2 м. Здесь были открыты остатки двух углубленных жилищ, несколько очагов, а также два целых человеческих скелета и отдельные кости еще как минимум трех индивидов (рис. 2). Коллекция находок включала почти 13 тыс. единиц, представленных обломками глиняных сосудов, изделиями и отходами производства из кремня, кварца, кости, рога и пр. Все это незамедлительно сделало памятник «одним из интереснейших для севера Европейской части СССР», как определила его сама Н.Н. Гурина [9, с. 27]. Автором раскопок он был интерпретирован как долговременное поселение [28, с. 169], на котором можно проследить постепенную смену культур при переходе от неолита к бронзе $[9$, с. $36 ; 28$, с. 153$]$. Являясь важным источником информации о быте и хозяйстве древнего населения Прибалтики, это поселение десятилетиями влияло на разные интерпретации материалов каменного века (типы жилищ, захоронение людей в жилищах и др.) не только в Эстонии, но и на соседних территориях [см., например: 29, s. 15; 30, 1k. 89-90]. Несмотря на многочисленность новых данных, полученных за более чем 60-летний период исследования региона, Рийгикюла I до сих пор является одним из немногих поселений в Эстонии с остатками жилищ, причем достаточно хорошей сохранности.

Со временем, при уточнении хронологии и культурной принадлежности материалов памятника (при повторном частичном анализе керамики, получении AMS датировок по человеческим костям и пр.) и соотнесении этих данных с общим археологическим фоном Нарвско-Лужского региона и Эстонии в целом, все яснее становилось, что это место не могло являться единым поселением, существовавшим здесь на протяжении тысячелетия, а посещалось людьми в разные периоды каменного и бронзового века для разных целей. В связи с этим возросла необходимость проведения повторного тщательного анализа всех материалов раскопок. Главной задачей при этом являлось выяснение стратиграфического распределения и относительной хронологии объектов культурного слоя, а также определение их абсолютного возраста с помощью AMS датирования контекстных костяных или роговых находок. Предварительные результаты этих работ представлены в данной статье.

\section{Палеосреда рийгикюльского микрорегиона}

Поселение располагалось на северо-восточной части песчаного хребта, протянувшегося с югозапада на северо-восток параллельно линии современного берега Финского залива [8, с. 7]. На югозападе хребет соединяется с высоким краем Балтийского глинта, а на северо-востоке, где его ширина не превышает 300 м, он ограничивается рекой Нарвой. К востоку от р. Нарвы продолжается холмистый, но уже более прерывистый рельеф. Сама стоянка Рийгикюла I находилась на относительно плоском участке рельефа, ограниченном на северо-западе от 
окружающего пространства небольшим всхолмлением. В настоящее время расстояние до берега моря от поселения составляет около 7 км, нижняя высотная отметка для поселений составляет около 6,5-7 м над уровнем моря. Поскольку в микрорегионе неоднократно проводились геологические, палеогеографические и палеоэкологические исследования, то история природных процессов, в том числе изменения Балтики, относительно хорошо известны [31-36].

Хребет, на котором находятся рийгикюловские памятники, представлял собой палеокосу, образовавшуюся после максимального уровня так называемой Литориновой трансгрессии (примерно 5300 кал. лет до н.э.) Балтийского моря [35, p. 920]. За палеокосой сформировалась полузакрытая лагуна, берега которой были заселены начиная примерно с 5100 кал. лет до н.э. [18, p. 174; 35, p. 926]. Южная часть лагуны начала зарастать примерно с 4000 кал. лет до н.э. и почти полностью высохла в течение нескольких веков [35, p. 929]. Изменение природной среды отразилось и на археологическом материале: наиболее молодые стоянки здесь расположены в основном поблизости к реке Нарве, которая впадала в лагуну, в то время как самые древние стоянки рассредоточены по всему внутреннему краю палеокосы. Рийгикюла I находится на краю хребта, в удобном месте для существования здесь берегового поселения каменного века как на этапе лагунного, так и речного вариантов палеоландшафта.

Во время проживания здесь населения каменного века весь берег был покрыт густым смешанным ле- сом. Сосны росли на сухих песчаных участках, небольшие массивы еловых лесов и широколиственных пород, таких как ольха и береза, располагались на более богатых и влажных почвах [32, с. 540; 34, p. 337-338; 37, lk. 65].

\section{Описание поселения Рийгикюла I}

и первоначальные интерпретации

На площади поселения были найдены остатки двух углубленных жилищ (рис. 1: $A ; 3)$. Жилище № 1 было раскопано частично (восточная половина), оно было значительно разрушено поздними перекопами. Углубленный примерно на 0,4 м в материк пол четко выделялся на фоне светло-желтого песка своим темным заполнением. В плане раскопанная часть ямы была округлой, диаметр около 8 м. В центре жилища, на 0,35-0,4 м выше основания пола, был открыт очаг № 1 (нумерацию очагов см. на рис. 4) - пятно золы, насыщенное мелкими угольками. К востоку от этого очага примерно на такой же высоте $(0,3-0,35$ м от основания пола постройки) располагался костяк взрослого человека (вероятно, женщины) 25-35 лет [38, p. 647], положенного вытянуто на спине, головой на север с незначительным отклонением на запад. Погребальная яма в ходе раскопок прослежена не была [8, с. 22-23]. Заполнение жилищной ямы было насыщено находками, особенно выделяется количество изделий и орудий из кости и рогов лося. На уровне положения костяка и очага заполнение жилища было перекрыто линзой ракушняка, выходящей за границы сооружения.

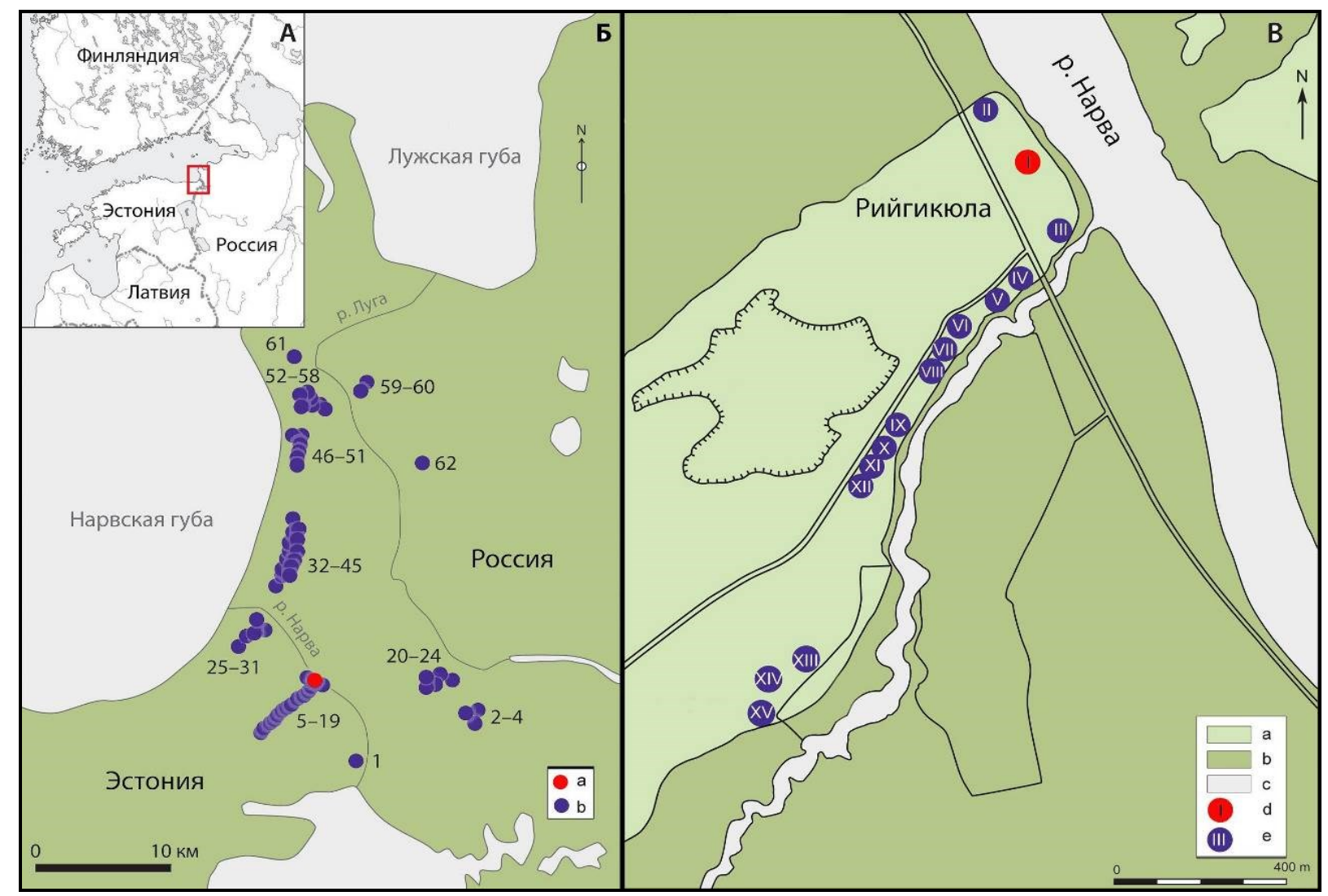

Рисунок 1 - Карта расположения поселения Рийгикюла I.

$A$ - Расположение региона исследования на карте части восточной Прибалтики; Б- регион Нарвско-Лужского междуречья

со всеми известными до 2016 г. [по 22, fig. 1] стоянками и поселениями каменного века: $a$ - поселение Рийгикюла I, $b$ - стоянки и поселения каменного века;

$B$ - поселение Рийгикюла [по 18, fig. 1: C]: a- палеокоса, $b$ - бывшее дно Литоринового моря, $c$ - современные реки, $d$ - поселение Рийгикюла I, $e$ - памятники Рийгикюла, с указанием номера 

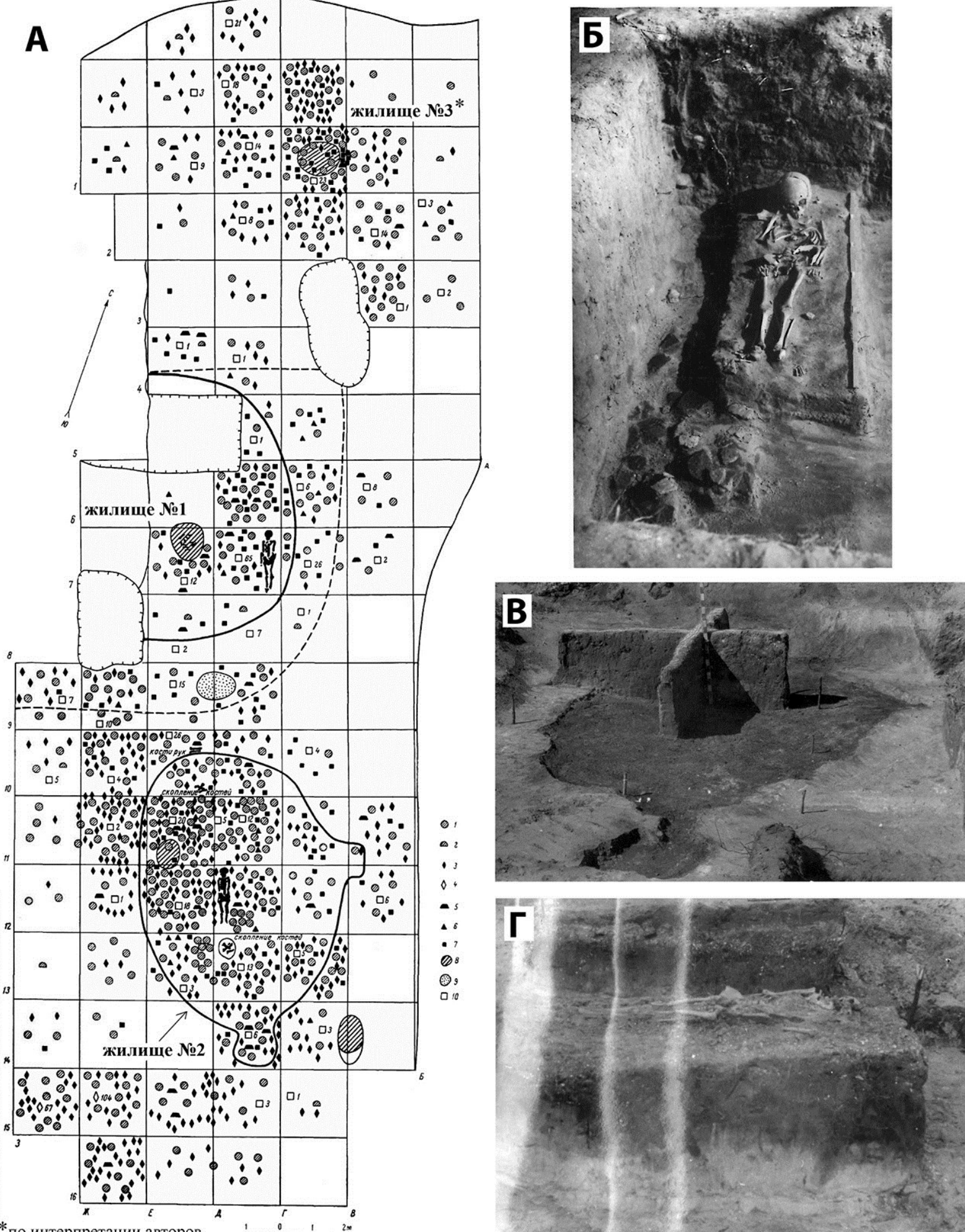

по интерпретации авторов

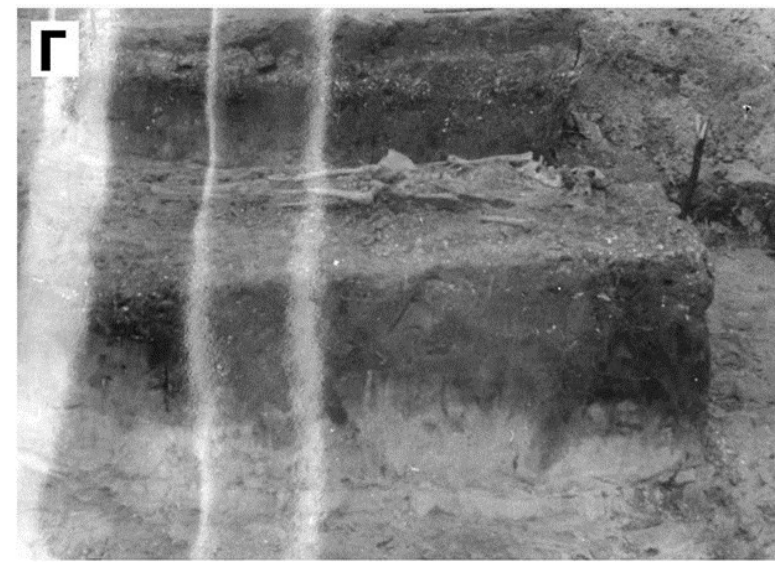

Рисунок 2 - Поселение Рийгикюла I.

$A$ - сводный план поселения: 1 - 20 обломков керамики, 2- 10 обломков керамики,

3- кремневые орудия и отщепы, 4- количество кремневых отщепов в скоплении, 5- кварцевые орудия,

6- роговые орудия, 7- кость со следами обработки, 8- очажные пятна, 9- яма с ракушняком, 10 - количество костей со следами обработки [по 10, с. 25, с дополнениями];

Б- погребение ребенка из жилища № 2 [по 10, с. 29]; B- контуры жилища № 2 на уровне материкового песка [по 10, с. 30]; Г- погребение взрослого индивида из жилища № 1 [по 10, с. 29]

Жилище № 2 так же четко выделялось на уровне материкового песка, в который оно было углублено примерно на 0,5 м. Яма размерами $6 \times 8$ м имела овальную форму. Пол постройки был ступенчатый, в южной части фиксировалась небольшая «ниша», пологий вход в виде «коридора» располагался в восточной, длинной стене сооружения [8, с. 23-29]. У западной стенки постройки на 0,6 м выше пола располагался очаг № 2 - зольное пятно, насыщенное мелкими угольками, диаметром около 1 м. В центральной части жилища примерно на 0,4 м выше пола был найден скелет ребенка 3-5 лет [38, р. 647], положенного вытянуто на спине, головой на север с незначительным отклонением на запад, как и в слу- 
чае с костяком в жилище № 1. Погребальная яма в этом случае также прослежена не была. Заполнение жилища было насыщено находками каменных и костяных предметов, обломками глиняных горшков. К югу от костяка ребенка, в его ногах, но ниже на $0,2-$ 0,25 м был найден развал сосуда культуры гребенчатой керамики с минеральной примесью, который Н.Н. Гурина, несмотря на разницу в высоте залегания, склонна была считать погребальным инвентарем $[8$, с. $29 ; 10$, с. 53$]$.

К юго-востоку от жилища № 2 был расположен очаг размерами $1,5 \times 0,75$ м, представлявший собой зольное пятно с мелкими угольками. Информацией о глубине его положения мы не обладаем. А между жилищами № 1 и № 2 была выявлена овальная в плане яма размерами $1,75 \times 1$ м с коническим дном, уходящим в материк, заполненная ракушняком [8, с. 166].

В северной части поселения был открыт еще один очаг (№ 3) овальной формы размерами ок. 1,2 × 1,4 м c большим скоплением находок в прилегающих квадратах. Глубина положения этого очага не ясна, т.к. ни в тексте, ни на плане этой информации нет, на стратиграфический разрез он тоже не попал.

По поводу очагов внутри построек у Н.Н. Гуриной, вероятно, не было устойчивого мнения, поскольку она их описывала то как приподнятые над полом очаги жилищ [28, с. 160], то связывала с погребениями [8, с. 163]. А сами погребения она относила к последнему этапу существования жилищ или чуть более позднему (но тем не менее неолитическому) времени [8, с. 29-30].

Среди материалов поселения первоначально было выделено три группы керамики: гребенчато-ямочная с примесью толченого кварца и дресвы, гребенчатоямочная с выгоревшей органической примесью и раковиной, а также посуда с большим количеством примеси раковины со штрихами на обеих поверхностях. Последний тип керамики (названный нарвским) на начальном этапе исследования Н.Н. Гурина отнесла к «позднему неолиту» или бронзовому веку [8, с. 174; 28, с. 167]. Затем, после определения Л.Ю. Янитсом этого материала как «предшествовавшего ямочногребенчатой керамике» [13, с. 26-65], она полагала, что нарвская культура сосуществовала с племенами гребенчато-ямочной керамики, говорила о скрещивании и постепенном слиянии двух различных групп населения - аборигенов с нарвской керамикой и пришельцев с гребенчато-ямочной керамикой, даже выделяла гибридную посуду [8, с. 174-175, 194]. Н.Н. Гурина отмечала, что все попытки выявить особенности вертикального распределения разных типов керамики на поселении не дали положительных результатов по причине: 1) многократного нарушения культурного слоя в результате сооружения жилых и хозяйственных конструкций и погребений в разные периоды или 2) из-за отсутствия заметного хронологического разрыва между этапами заселения этого места, связанными с разными типами керамики [8, с. 174]. При этом, говоря о совместном залегании на некоторых участках поселения нарвской и гребенчатой керамики, писала, что нельзя разделить их по высоте, поскольку смешанный тип керамики залегает «почти на одной высоте» с нарвской, «выше лишь на 20 см» [8, с. 175].
Каменный, костяной и роговой инвентарь поселения автором описывался практически единым массивом, без внимания к вертикальному и даже планиграфическому распределению, поскольку практически не имеет ярких типологических различий. Отдельно анализировались только отпиленные под углом эпифизы крупных копытных животных и рога лося, найденные на памятнике в большом количестве. Особенно большая концентрация их была связана с постройкой № 1, что дало возможность предположить наличие в ней мастерской по изготовлению т.н. «орудий под $45^{\circ} »$ и мотыг [8, с. 123-135; 39].

\section{Стратиграфия памятника}

Согласно описанию Н.Н. Гуриной, верхний слой поселения был в основном представлен дерном (рис. 3), часто нарушенным и перемешанным с выбросом из поздних ям. На некоторых участках мощность его достигала 0,5 м [8, с. 22]. Ниже залегал слой перемешанного песка средней мощностью 0,2 м, иногда - до 0,4 м, а на некоторых квадратах он отсутствовал. Н.Н. Гурина полагала, что это был культурный слой древнего поселения, нарушенный во время существования здесь современной деревни. Далее непосредственно следовал непотревоженный культурный слой мощностью 0,4-0,7 м и до 1,2 м на площади жилищ. Он был представлен супесью почти черного цвета. В среднем отделе культурного слоя были выявлены относительно мощные линзы ракушняка (Unio). Но Н.Н. Гурина не выделяла эти линзы из общей толщи культурного слоя, порой описывая их просто как «примесь раковин» [8, с. 22]. Планиграфически основные скопления раковины были прослежены на площади жилищ, по краям поселения они была незначительны или вовсе отсутствовали. Материк был представлен светло-желтым дюнным песком.

Какие-то особые условия, сохранившие насыщенный черный окрас культурного слоя, и линзы ракушняка, по всей видимости, способствовали хорошей сохранности костяного и рогового материала, что обычно не свойственно для неторфяниковых памятников каменного века этого региона.

\section{Современный этап исследования,}

состояние источника и методы работы

Спустя 65 лет после открытия памятника интерес к нему не только не теряется, но и возрастает, что связано с богатством и разнообразием информации, содержащейся в его находках и объектах, дающей почву для новых исследований, предположений и интерпретаций. Так, например, большое скопление находок вокруг очага № 3 позволило предположить наличие здесь еще одного жилища [41, p. 237]. А недавние исследования двух захоронений, найденных в жилищах № 1 и № 2, показали их принадлежность к периоду бронзового века [38, p. 648; 42].

Таким образом, в настоящее время появилось много вопросов, касающихся относительной и абсолютной хронологии объектов и находок памятника Рийгикюла I. Поэтому было решено вернуться к материалам поселения.

Ревизия материалов памятника, доступных на сегодняшний день, показала, что, к сожалению, большое количество информации утрачено безвозвратно в силу как объективных (особенности методики раскопок и документации того времени), так и субъек- 
тивных (утрачена большая часть документации и часть находок, на многих находках не читаются полевые номера и пр.) причин. Памятник раскапывался по квадратам $2 \times 2$ м по условным горизонтам, но мощность этих горизонтов установить не представляется возможным. По результатам раскопок был сделан только один общий план поселения на уровне материкового песка, на который были наложены разновременные объекты и находки культурного слоя, несмотря на его значительную мощность, промежуточные планы по горизонтам не делались. Высотные отметки на плане, как и на стратиграфических разрезах, отсутствуют. Находки в поле собирались по квадратам по условным горизонтам и получали отдельные полевые номера, но сейчас они хранятся в Музее антропологии и этнографии им. Петра Великого (Кунсткамере) Российской академии наук по музейной описи (коллекция № 6719), а «ключ» к полевым номерам отсутствует, поскольку все полевые описи утрачены. В связи с этим можно только предполагать, что чем больше полевой номер, тем глубже залегали эти находки в слое в пределах одного квадрата. Поскольку все объекты и находки нанесены на единый план без высотных отметок, то при отсутствии этих объектов на стратиграфических разрезах и в текстовом описании мы не можем установить уровень их расположения в толще культурного слоя.

Основу методики работы с материалами памятника в этом случае представлял пространственный анализ и трехмерное моделирование распределения объектов культурного слоя и, по возможности, находок, основанный на сведении всех стратиграфических разрезов с планом и фотографиями раскопа, а также привлечении описаний памятника автором раскопок в полевых дневниках, отчетах и текстах публикаций. Это, несмотря на значительные пробелы в имеющейся информации, позволило выделить в толще культурного слоя разновременные уровни, а также дополнить чертежи некоторыми не отмеченными на плане ямами, очагами и конструкциями, связать с объектами предметы с четкой культурной атрибуцией и выбрать для датирования кости животных и костяные изделия.
Выявлено три не попавших на общий план поселения объекта. В тексте книги [8, с. 23] описан очаг (округлое пятно диаметром около 1 м, насыщенное золой и мелкими угольками), располагавшийся к югу от жилища № 1 , но на плане и стратиграфических разрезах его нет, поэтому точнее сказать о его положении ничего нельзя. На стратиграфическом разрезе северной части раскопа (пикеты Б3-Б1) есть две ямы, описание которых в текстах отчетов и прорисовка на плане отсутствуют. Судя по стратиграфии, можно заключить, что к востоку от очага № 3 в толще культурного слоя, под перемешанным песком, располагалась яма предположительно диаметром около 1,3 м, глубиной 0,4-0,45 м, заполненная птичьими костями и рыбьей чешуей (рис. 3). А юго-восточнее на 0,5 м от этой ямы на уровне материкового песка находилась другая (очажная?) яма возможным диаметром около 1,45 м, глубиной порядка 0,2 м, заполненная углем.

Несмотря на «спрессованность» всех находок в единый пласт, их планиграфия показывает основные зоны концентраций, четко связанные с постройками и очагами. Стоит отметить в этом случае важность нанесения на план ямы, заполненной углем (пикет Б2), которая была прорисована только на стратиграфическом разрезе, поскольку ее наличие объясняет концентрацию глиняных и костяных находок в этом месте, что в свою очередь косвенно указывает на то, что яма эта являлась, скорее всего, очагом (№ 4, pис. 4: $A, Б$ ). Зоны концентраций разных категорий находок распределяются по площади поселения немного по-разному: керамика (рис. 4: $A$ ) и кость (рис. 4: Б) в большей степени связываются с контурами построек, кремень (рис. 4: $B$ ) смещен от центра сооружений и четко соотносится с очагами № 2 и № 3 (в постройке № 1 кремень отсутствует), есть отдельное скопление в южной части раскопа вне объектов; предметы из кварца и рога скоплений как таковых не показывают в силу своей малочисленности, но лежат около построек. Наибольшее скопление фрагментов керамики связано с очагом № 2, а костяной материал в большей степени сконцентрирован в контурах жилища № 1.
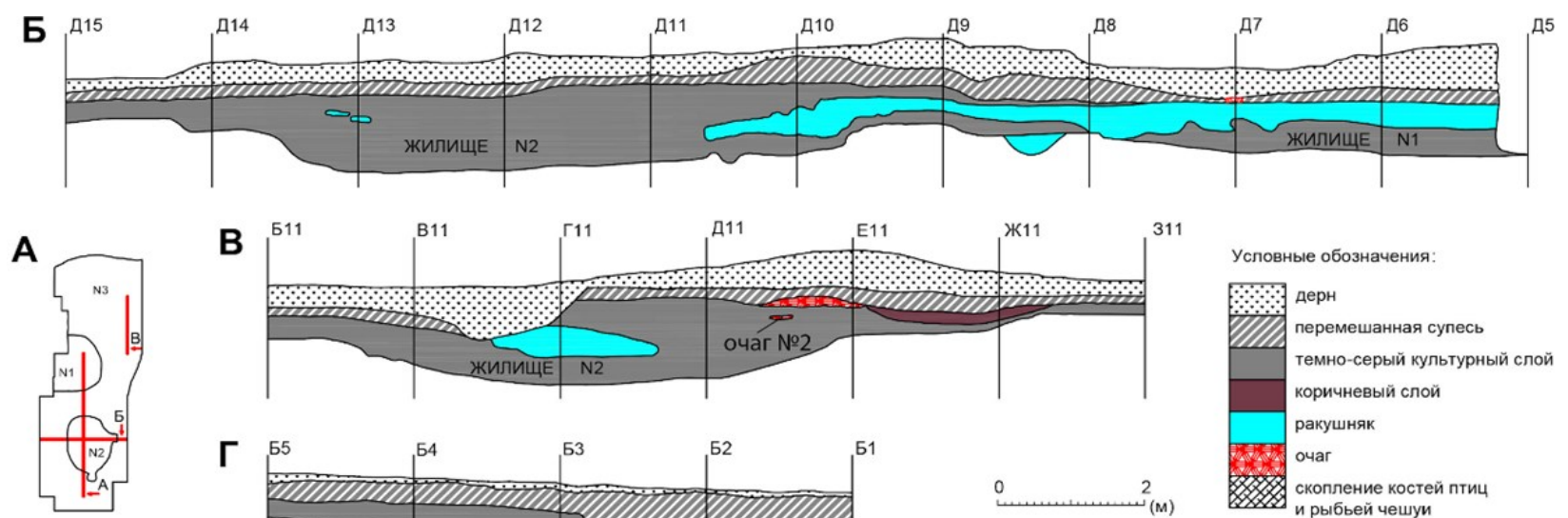

B

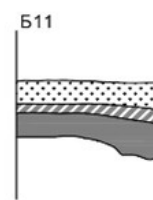

$\Gamma$

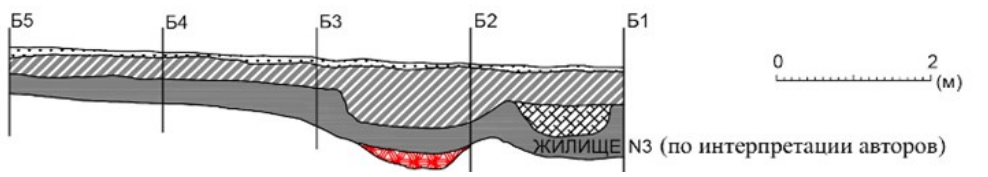

Рисунок 3 - Стратиграфия поселения Рийгикюла I.

$A$ - схема расположения стратиграфических разрезов на плане поселения;

Б- стратиграфический разрез по пикетам Д15-Д5 [по 8, рис. 14: 5 , с дополнениями];

$B$ - стратиграфический разрез по пикетам Б11-311 [по 8, рис. 14: $A$, с дополнениями];

Г- стратиграфический разрез по пикетам Б5-Б1 [по 40, с дополнениями] 


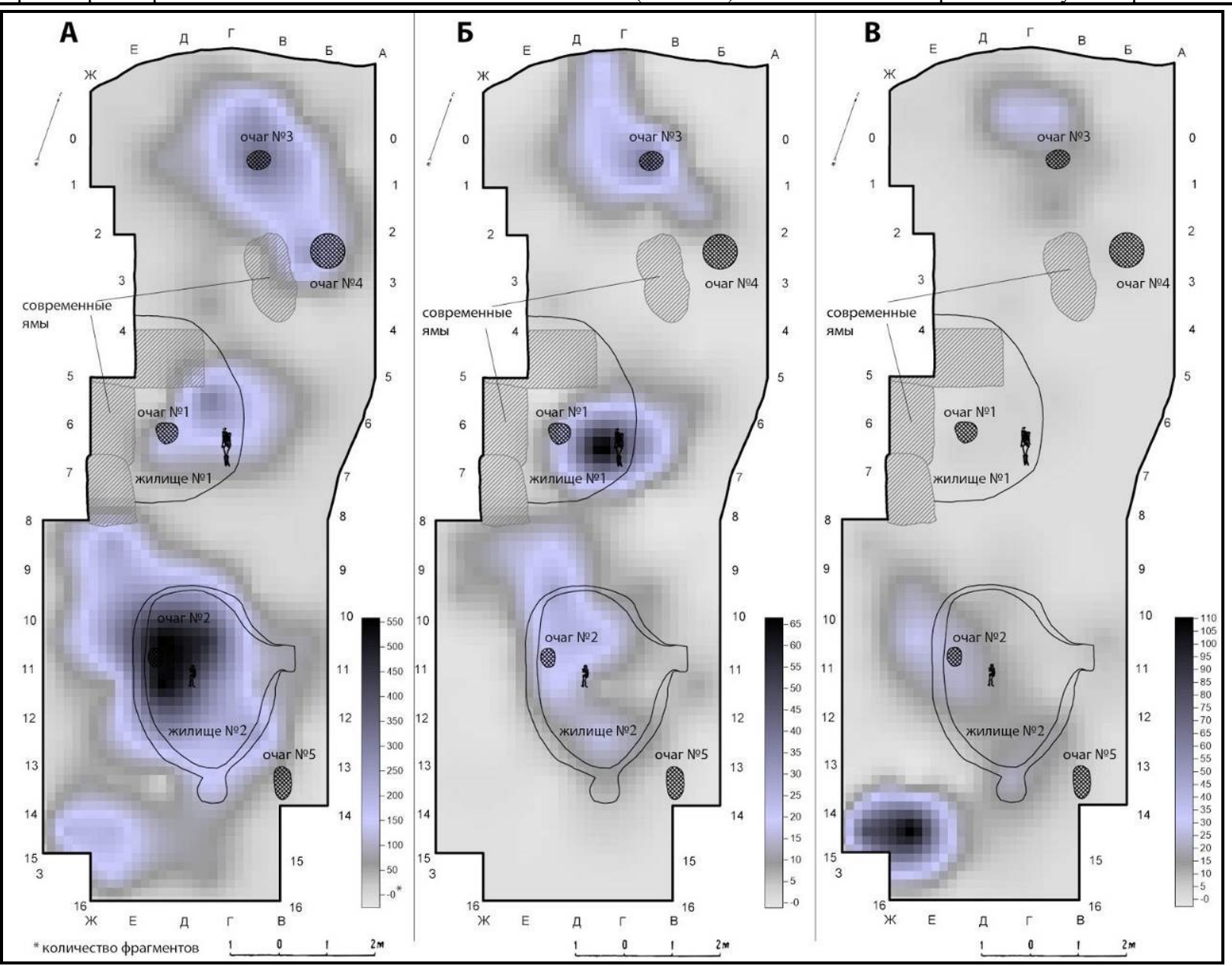

Рисунок 4 - Планиграфия находок на поселении Рийгикюла I. $A$ - фрагменты глиняной посуды; Б- костяные изделия и их обломки; $B$ - кремневые орудия и отходы производства

Особенно обращает на себя внимание концентрация находок у очага № 3. По своему качественному и количественному составу предметов она хорошо сопоставима с концентрацией находок в жилищах № 1 и № 2, очевидно наличие большого количества фрагментов глиняной посуды и изделий из кости. Но кроме того, на имеющемся стратиграфическом разрезе по пикетам Б5-Б1 с этой части поселения четко видно «врезание» культурного слоя в материк примерно на 0,3 м на уровне пикета Б2 (рис. 3: $Г$ ), что может быть остатками углубленного пола постройки, не зафиксированного в ходе раскопок. К сожалению, проследить это можно только на одном единственном длинном стратиграфическом разрезе, поскольку остальные профиля с этой части раскопа сделаны по отдельным квадратам и не стыкуются друг с другом. Тем не менее мы можем подтвердить наличие еще одной углубленной постройки (№ 3), которая, вероятно, имела не столь ярко выраженную конструкцию, вследствие чего не была выявлена во время полевых работ. Уровень положения очага № 3 в данном случае мы, к сожалению, установить не можем ввиду отсутствия высотных отметок, но его положение в центре скопления находок дает основание предполагать его связь с ними. Форму и размер жилища тоже определить не представляется возможным, концентрация находок образует округлое пятно диаметром около $6 \mathrm{M.}$

Отдельно следует отметить расположение основной зоны концентрации находок в постройке № 2 . Она сдвинута к западной стенке жилища и выходит за его границы, тяготея в большей степени к очагу № 2, размеры ее составляют порядка $4 \times 3$ м. Учитывая этот факт и высоту положения очага, можно предположить существование на этом месте некой жилой конструкции (№ 4), которая наложилась на постройку № 2 после ее разрушения. В стратиграфическом разрезе это не было прослежено, поэтому ничего более конкретного про ее особенности сказать нельзя.

В южном углу раскопа выделяется зона концентрации фрагментов глиняных сосудов и кремня, не связанная с какими-либо объектами культурного слоя.

Анализ стратиграфии поселения указывает на то, что культурный слой имел два пласта (верхний и нижний). Сама Н.Н. Гурина в полевом отчете отмечала, что «наибольшая концентрация ракушек прослеживалась в середине культурного слоя, являясь как бы границей, отделяющей более светлую его часть от более темной» [9, с. 28], но на чертежи эта граница нанесена не была. В настоящее время провести ее тоже затруднительно, в силу недостатка информации о том, как она могла проходить на тех участках, где нет прослойки ракушек. Тем не менее стратиграфически можно выделить как минимум 3 уровня залегания разновременных объектов. К нижнему отделу культурного слоя относятся остатки углубленных в материк жилищ и ям, к среднему (под прослойками ракушняка) - захоронения и очаги; в верхнем отделе (под насыпным грунтом) выявлены очаги и ямы. Но первоначальные уровни поверхностей, с которых были впущены постройки и погребе- 
ния, установить практически невозможно. Прослойка раковин Unio, которую Гурина описывала в качестве заполнения построек поселения, на самом деле перекрывала только площадь жилища № 1, выходя за ее границы, а в жилище № 2 присутствовала только в северной части, как бы «затекала» в него, повторяя формы жилищной западины. Это указывает на то, что слой ракушек сформировался после того, как обе постройки прекратили свое существование. Очаг № 1, судя по его высоте, должен был располагаться на уровне ракушняка (в его нижней части), а очаг № 2 - выше этой прослойки - в верхнем отделе культурного слоя.

Таким образом, в итоге повторного изучения материалов памятника удалось установить некоторые особенности пространственного распределения находок и объектов культурного слоя, а также выделить новые объекты и комплексы. Но чтобы понять связь их друг с другом, необходимо установить хронологию.

\section{Возможности определения}

относительной и абсолютной хронологии

Лучшим методом выяснения внутренней хронологии памятника, несомненно, является радиоуглеродное датирование, хотя перемешанность слоя и сложности установления точной привязки находок к объектам создают определенные проблемы. В настоящее время уже исследованы два захоронения, найденные в жилищах № 1 и № 2. AMS методом по человеческим костям получены радиоуглеродные даты: погребение взрослого из жилища № 1 дало возраст $3113 \pm 20$ ВР, KIA-48835 (1435-1370 (59\%) кал. лет до н.э.; 1355-1300 (36\%) кал. лет до н.э.); погребение ребенка в жилище № $2-3013 \pm 19$ ВP, KIA48836 (1380-1350 (7\%) кал. лет до н.э.; 1305-1195 $(88 \%)$ кал. лет до н.э.), указывающие на принадлежность их к бронзовому веку [38, p. 648]. По стабильным изотопам углерода $(\delta 13 \mathrm{C})$ и азота $(\delta 15 \mathrm{~N})$ эти даты надежны и не имеют значительного резервуарного эффекта [38, p. 652]. Сейчас для датирования вы- брано несколько костяных предметов из заполнения жилищ, однако результаты еще не получены.

Для прибрежной зоны Балтийского моря в Эстонии разработан метод датирования по береговой хронологии, в которой учтены изменения Балтики за последние 7500 лет [43]. Поскольку в целом в настоящее время история водного режима и береговые процессы Балтийского моря в Нарвско-Лужском регионе изучены достаточно хорошо [35; 36], то можно датировать археологические памятники, непосредственно связанные с морским побережьем с точностью в 100-200 лет. Но, к сожалению, это неприменимо к памятнику Рийгикюла I, так как собранный археологический материал многокультурный и разновременный, а само место было пригодным для поселения в течение длительного времени. Поэтому достоверно установить, было ли поселение связано с рекой или с морским (лагунным) берегом, невозможно. Фаунистические остатки с Рийгикюла I тоже не помогают решить этот вопрос, потому что как обычно для материковых памятников Эстонии, которые находились на берегу моря, в устьях или эстуариях рек [44, p. 14-17; 45], часть из рийгикюльских костей животных связана с морем, а другая часть с речными и лесными источниками (рис. 5). Среди найденных в культурном слое костей преобладали кости лося, кабана, тура, бобра, медведя и куницы. Морские животные были представлены костями тюленей и морских свиней; были также кости птиц (192) с абсолютным преобладанием водоплавающих птиц; а также кости пресноводных рыб (292): сиг, судак и щука [46, с. 437-438; 8, табл. 5]. Стоит отметить огромное количество пресноводных раковин Unio.

Поэтому пока мы вынуждены использовать только метод косвенного датирования - типо-хронологию. В нашем случае единственным датирующим материалом является керамика, которая имеет типохронологические рамки по датированным комплексам Эстонии и Западной России.

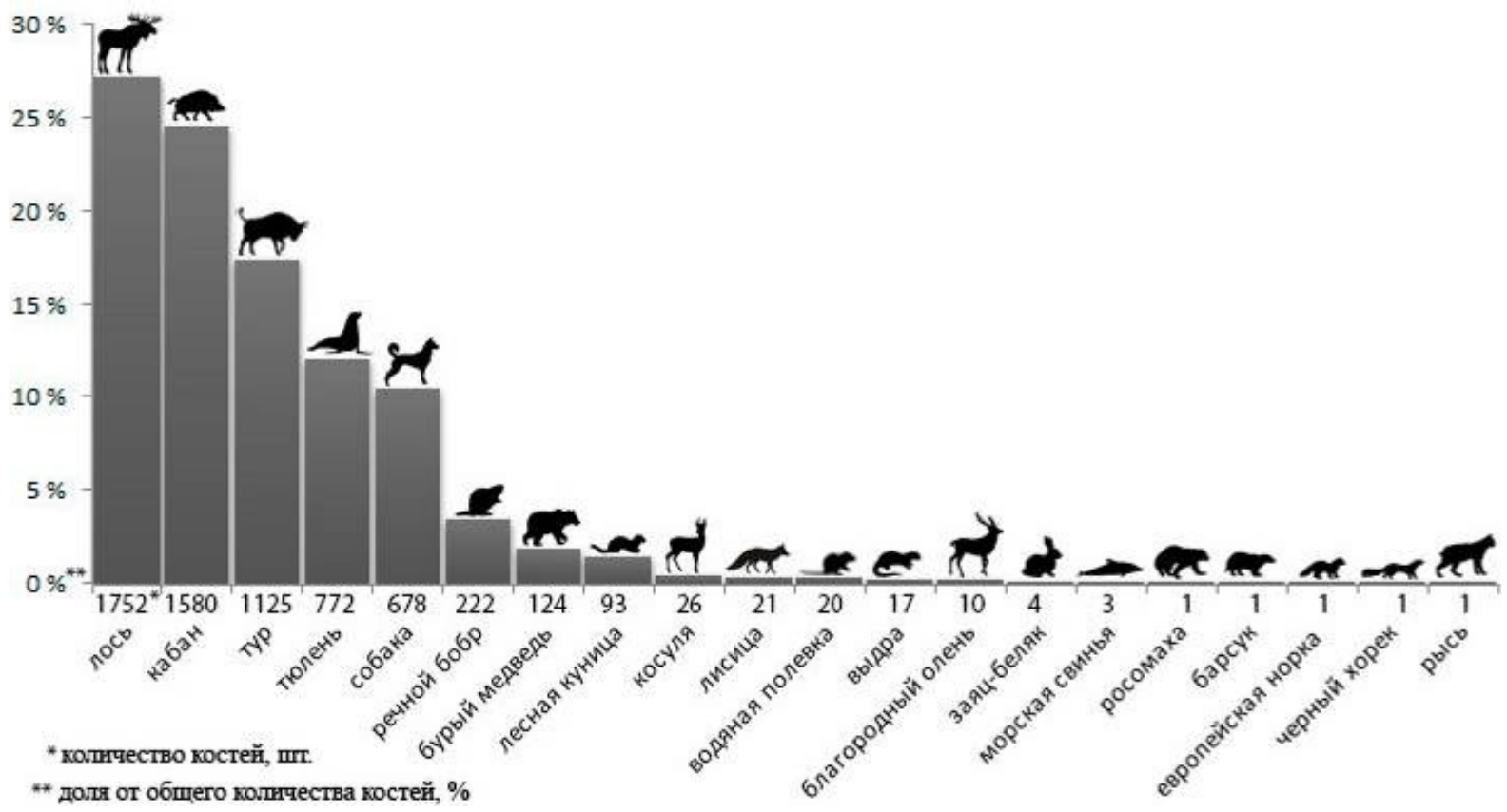

Рисунок 5 - Остеологический материал поселения Рийгикюла I

[по 46, р. 437-438] 


\section{Анализ фрагментов глиняной посуды}

На памятнике Рийгикюла I массово представлены фрагменты как нарвской, так и гребенчатой керамики, очевидного преобладания одного из типов не выявляется, немногочисленны фрагменты шнуровой керамики (рис. 6). Коллекция памятника хранится в соответствии с тремя большими группами, выделенными Н.Н. Гуриной, и множеством более дробных, выделенных преимущественно по элементам орнамента (отпечаткам гребенки, ямкам, нарезкам и т.д.), по размеру (отдельно выбраны очень мелкие сосуды), по составным частям сосудов (днища, венчики). Небольшая часть материала хранится в соответствии с выделением т.н. «особых» сосудов, описанных в тексте монографии - прим. «особый сосуд с сильным обжигом» $[8$, с. 48-49, табл. 1]. Основная часть мелких фрагментов определена как «резерв» и хранится большими объемами, разделенная по трем основным типам.

Стоит также отметить, что если нарвская керамика выделена по целому ряду признаков, то различия между «гребенчато-ямочной с органической примесью и раковиной» и «гребенчато-ямочной с неорганической примесью» определены только по виду примеси. Керамика с комбинированной примесью отнесена к первой группе.

Основной целью нашей работы был анализ фрагментов глиняной посуды из квадратов с площади построек, поскольку это единственная привязка материала к объектам. В силу отсутствия части документации и самих находок, а также ввиду их сохранности, удалось выделить находки только для части рассматриваемых нами квадратов (рис. 7: $A$ ): шесть квадратов для постройки № 1; для постройки № 2 только два самых крайних, и те частично; для жилища № 3 было выбрано 5 квадратов с наибольшей концентрацией находок вокруг очага. Однако и из выделенных квадратов удалось найти и идентифицировать лишь около 55\% керамики (1225 фрагментов). В результате проведенного анализа удалось выявить некоторые особенности планиграфического распределения фрагментов разных типов сосудов.

На площади постройки № 1 доминирует нарвская керамика (рис. 7: Б). Сделать заключение по материалу из постройки № 2 сложно, ввиду ограниченности данных. Кроме того, как мы уже установили, выше нее располагалось еще одно более позднее сооружение № 4. Так, в одном квадрате с края площади постройки № 2 преобладает нарвская керамика, в другом - гребенчатая с минеральной примесью (рис. 7: $B)$. Поэтому здесь важным источником информации может послужить описание Н.Н. Гуриной, из которого известно, что близко к уровню пола жилища № 2 рядом с погребением находились развалы сосудов с
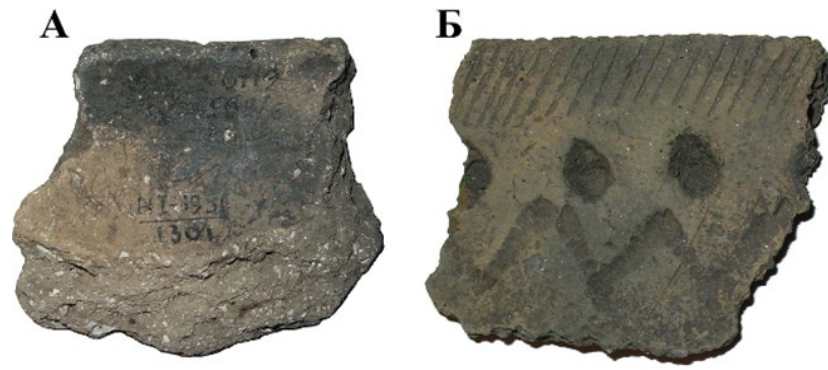

гребенчато-ямочной орнаментацией, отнесенные изначально к погребальному инвентарю [10, с. 53]. На площади постройки № 3 материал смешанный (рис. 7: Г), с преобладанием гребенчатой керамики примерно в равных пропорциях с минеральной и органической примесью (незначительно преобладает минеральная примесь).

Нарвская культура в целом в Эстонии и Западной России датируется периодом 5200-3900 кал. лет до н.э. [47, р. 77]. Гребенчатая керамика с минеральной и органической примесью (так называемая «типичная гребенчатая керамика») имеет в Эстонии даты около 3900-3200 кал. лет до н.э., а гребенчатая керамика с органической примесью («поздняя гребенчатая керамика») - ок. 3700-1800 кал. лет до н.э. [cм. 47, p. 76; 48, p. 30]. Но пока все еще недостаточно радиоуглеродных дат для финального этапа гребенчатой керамики с минеральной примесью, поэтому ее верхняя дата, вероятно, в настоящее время не является окончательной. Для культуры шнуровой керамики в Эстонии и Западной России время существования определяется периодом 2800-2000 кал. лет до н.э. [49, р. 105]. Таким образом, отталкиваясь от найденных на поселении типов керамики, мы имеем довольно широкие хронологические рамки возможности существования поселения, которое очевидно посещалось неоднократно. По типо-хронологии это промежуток примерно 5200-1800 кал. лет до н.э.

Если выводы, полученные по горизонтальному распределению керамики, верны, то жилище № 1 следует связывать с ранним этапом заселения этого места - с нарвской культурой и датировать примерно периодом 5200-3900 кал. лет до н.э. Кроме того, на площади этой постройки была выявлена наибольшая концентрация опиленных эпифизов - отходы производства орудий под $45^{\circ}$, и самих орудий, которые на территории Эстонии и Латвии имеют параллели именно в материалах нарвской культуры, хотя некоторые экземпляры были найдены и на более ранних памятниках $[30,1 \mathrm{k} .63 ; 50, \mathrm{lk} .86 ; 51$, с. 25-26]. Такая датировка косвенно подтверждается и отсутствием кремня на площади жилища. Поскольку в Северной части Эстонии нет природных выходов кремня [52], то в нарвское время этот материал на данной территории использовался крайне редко, и основным сырьем был кварц. На чистых нарвских памятниках с Рийгикюлы и в целом из Нарвско-Лужского междуречья кремня практически не найдено.

Жилище № 2 сложно определить однозначно: нарвская или гребенчатая керамика с минеральной примесью; но скорее всего его стоит связывать с культурой гребенчатой керамики и датировать предварительно периодом 3900-3200 кал. лет до н.э.
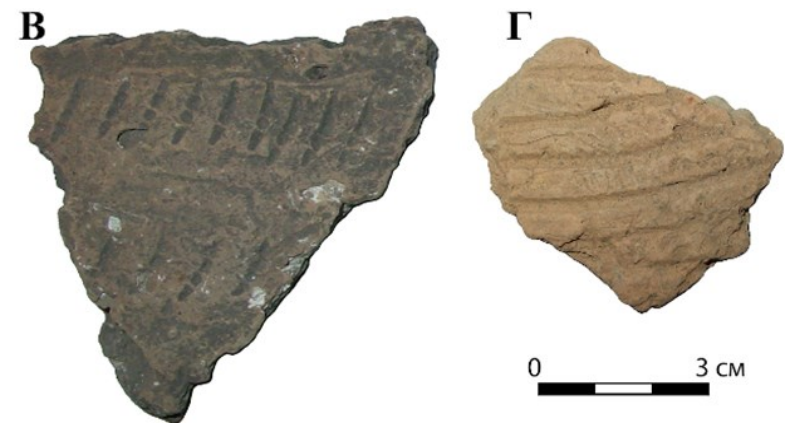

Рисунок 6 - Фрагменты разных типов глиняных сосудов, представленных на поселении Рийгикюла I (фото: А. Крийска). $A$ - нарвская керамика; 5 - гребенчатая керамика с минеральной примесью; $B$ - гребенчатая керамика с примесью раковин; $\Gamma$ - шнуровая керамика 


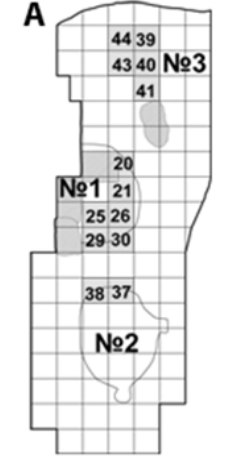

\section{Б}

Жилище №1

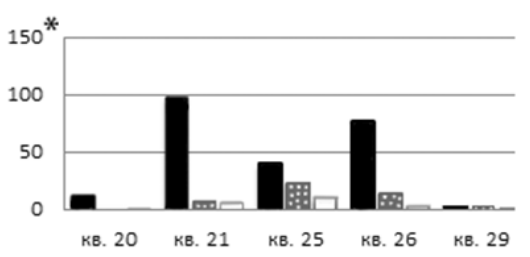

- нарвская

* количество фрагментов, шг.

\section{$\Gamma$}

\section{Жилище №2}

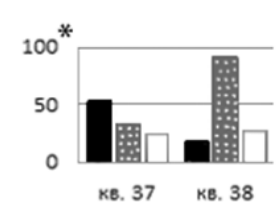

гребенчатая с минеральной примесью

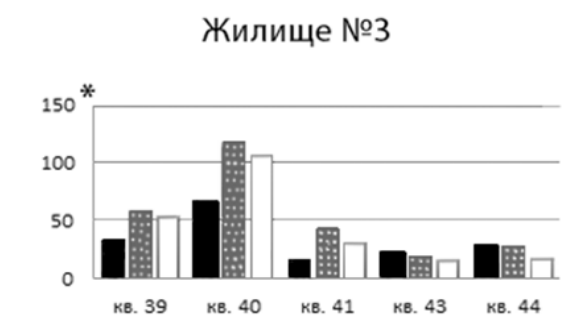

гребенчатая с органической примесью

Рисунок 7 - Распределение разных типов керамики в жилищах.

$A$ - план поселения с выделенными квадратами, керамика из которых была проанализирована; Б- жилище № 1; B-жилище № 2; Г- жилище № 3

Впервые в данной работе определено жилище № 3 вокруг очага № 3, связанное с гребенчатой керамикой, в равных долях с минеральной и органической примесью. Это косвенно подтверждается и концентрацией кремня на этом участке, поскольку в период существования культуры гребенчатой керамики до Балтики в целом и до Нарвско-Лужского региона в частности доходило довольно много кремня из разных источников, и в начале этого этапа данный вид сырья превалировал над кварцем [27, 1k. 18-19; 30, lk. 93]. Предварительно можно датировать это жилище в рамках 3900-3200 кал. лет до н.э.

С выделенной нами жилой конструкцией № 4, которая перекрывала западную часть жилища № 2, связывается гребенчатая керамика с минеральной примесью, по которой можно предварительно определить хронологические рамки ее существования промежутком 3900-3200 кал. лет до н.э.

\section{Выводы}

В ходе проведенного пересмотра материалов поселения Рийгикюла I удалось определить новые, не выявленные в ходе полевых работ объекты, установить планиграфическую взаимосвязь находок и объектов культурного слоя памятника, а также установить относительную хронологию событий, происходивших на площади поселения в каменном и бронзовом веках.

- Подтвердилось наличие жилища № 3 с очагом в центре в северной части поселения, которое выделяется не только концентрацией находок, имеющей такие же качественные и количественные характеристики, как в жилищах 1 и 2, но и западением культурного слоя, «читаемого» в стратиграфическом разрезе.

- Было установлено, что очаги № 1 и № 2, обнаруженные в контурах жилищ № 1 и № 2, не связаны с этими постройками.

- По концентрации находок вокруг очага № 2 выделена новая жилая конструкция № 4, которая частично перекрывала западную часть постройки № 2 .

- Концентрации находок по горизонтали четко локализуются вокруг очагов и на площади построек, их стратиграфическое распределение установить невозможно. Скорее всего, имела место перемешанность слоя по вертикали ввиду разновременных заселений, но утверждать это мы не можем из-за отсутствия высотных отметок.

- Наличие на площади поселения еще как минимум трех очагов говорит о существовании здесь и других (возможно, разновременных) поселенческих структур.

- Постройка № 1 связана с нарвской керамикой. Жилище № 2 - сложно определить однозначно: нарвская/гребенчатая керамика с минеральной примесью, но скорее гребенчатая. Наличие жилой конструкции № 4 остается в области предположений, как и состав керамики из скопления вокруг ее очага. По тем данным, которые мы имеем, - это гребенчатая керамика с минеральной примесью. Постройка № 3 связана с гребенчатой керамикой, в равных долях с минеральной и органической примесью.

- Уровень, с которого были сделаны погребения в постройках, установить затруднительно, но поскольку в верхнем отделе культурного слоя находилось сооружение № 4 с очагом № 2 в центре с материалами гребенчатой керамики, то уровень этот должен быть выше, и, вероятно, он был разрушен более поздней распашкой. Кроме того, попадание обоих костяков на площадь построек может указывать на то, что на момент их захоронения жилищные западины были видны на поверхности, вследствие чего эти места и были выбраны. Сложно сказать, являются ли другие человеческие кости, найденные на памятнике, частью разрушенного могильника.

- Концентрации кремня только вокруг очагов № 2 и № 3 - это своего рода хронологический (культурный) маркер, поскольку появление или исчезновение этого вида сырья на территории Северной Эстонии связано с определенными культурными этапами. Так, для рассматриваемого периода и места кремень связан с носителями культуры гребенчатой керамики. В жилище № 1 кремня нет вообще, в жилище № 2 мало.

В итоге можно заключить, что памятник представлял собой ряд разновременных поселений и стоянок, которые могли существовать здесь как сезонно, так и круглогодично. Первое заселение этого места связано с культурой нарвской керамики, постройка № 1 относится, по всей видимости, к этому периоду. Ко времени обитания здесь носителей культуры гребенчатой керамики можно отнести, вероятно, жилище № 2, точно - жилище № 3 и конструкцию № 4 . Затем территория посещалось носителями культуры шнуровой керамики, но эти материалы столь немногочисленны, что можно предполагать только их кратковременное проживание. А уже в середине бронзового века на это место пришли люди хоронить своих покойников, причем на места бывших построек каменного века, впадины от которых могли быть еще видны на поверхности в то время.

Благодарности. Благодарим за помощь в работе с материалами к.и.н., научного сотрудника Отдела археологии Музея антропологии и этнографии им. Петра Великого (Кунсткамеры) Российской академии наук Дмитрия Владимировича Герасимова. 


\section{Список литературы:}

1. Kriiska A. Stone Age settlements in the lower reaches of the Narva river, North-Eastern Estonia // Coastal Estonia. Recent Advances in Environmental and Cultural History. PACT 51. Rixensart, 1996. P. 359-369.

2. Indreko R. Kaevamistest Siivertsis Narva linna piiril Tuuliku t. 30, Siirak Munaku krundil. Tallinn, 1931. Рукопись в археологической научной коллекции Таллинского университета.

3. Indreko R. Eesti ürgaeg, in Elav Teadus, 69. Tartu: Eesti Kirjanduse Selts, 1937. 124 lk.

4. Indreko R. Muinasaegsest kalandusest Eestis // Kalanduskoja Toimetised. 1937. № 2. Lk. 1-17.

5. Indreko R. Kaevamised 2. VII 40. Ekaterina Hämelaineni (Jaan Saare) tl. maal Narvataguse, Narva vld. Lommi kruusaaugus, Notika oja ääres, mis jookseb Luuga jõkke. Tallinn, 1940. Рукопись в археологической научной коллекции Таллинского университета.

6. Indreko R. Die mittlere Steinzeit in Estland. Mit einer übersicht über die Geologie des Kunda-Sees von $\mathrm{K}$. Orviku, in Kungliga Vitterhets Historie och Antikvitets Akademiens handlingar, 66. Stockholm: Wahlström \& Widstrand, 1948. $427 \mathrm{~s}$.

7. Гурина Н.Н. Полевой дневник. Рукопись // Архив ИИМК РАН. Ф. 35. Д. 73. 1951. 58 л.

8. Гурина Н.Н. Из истории древних племен западных областей СССР (по материалам Нарвской экспедиции) // Материалы и исследования по археологии СССР. Вып. 44. Л.: Наука, 1967. 212 с.

9. Гурина Н.Н. Отчет о работе Нарвской археологической экспедиции и карельского отряда торфяниковой экспедиции за 1951 г. // Архив ИА РАН, Москва. Р. 1. Д. 577.57 л.

10. Гурина Н.Н. Отчет о работе Нарвской экспедиции 1952 г. // Архив ИА РАН, Москва. Р. 1. Д. 719.72 л.

11. Гурина Н.Н. Отчет о полевых археологических работах в 1953 г. в Карело-Финской ССР, Ленинградской области и Эстонской ССР // Архив ИА РАН, Москва. Р. 1. Д. 796. 35 л.

12. Moora H. Eine steinzeitliche Schlangenfigur aus der Gegend von Narva // Studia neolithica in honorem Aarne Äyräpää. Suomen Muinaismuisoyhdistyksen Aijakauskirja, 58. Helsinki: K.P. Puromihen Kirjapaino O.Y., 1957. S. 225-232.

13. Янитс Л.Ю. Поселения эпохи неолита раннего металла в приустье р. Эмайыги (Эстонская ССР). Таллин: АН ЭССР, Институт истории, 1959. 382 с.

14. Гурина Н.Н. Древняя история северо-запада Европейской части СССР // Материалы и исследования по археологии СССР. Вып. 87. М.-Л.: Наука, $1961.588 \mathrm{c}$.

15. Янитс Л.Ю. Новые данные по мезолиту Эстонии // Материалы и исследования по археологии СССР. Вып. 126. М.-Л.: Наука, 1966. С. 114-123.

16. Эфендиев Э.Ф. Раскопки в западном Принаровье // Археологические открытия 1981 года. М.: Наука, 1983. С. 396.

17. Петренко В.П., Эфендиев Э.Ф. Работы на территории Эстонии и Ленинградской области // Археологические открытия 1983 года. М.: Наука, 1985. С. 453.

18. Kriiska A. Formation and Development of the Stone Age Settlement at Riigiküla, Northeastern Estonia // Environmental and Cultural History of the Eastern Baltic Region. PACT 57. Rixensart: Council of Europe, 1999. P. 173-183.

19. Герасимов Д.В., Крийска А., Лисицын С.Н. Памятники каменного века юго-восточного побережья
Финского залива: хронология и геоморфология // Краткие сообщения Института археологии РАН. 2012. № 227. С. 241-247.

20. Герасимов Д.В., Крийска А., Холкина М.А. Археологические исследования 2012 г. на Кудрукюльской палеокосе в Нарвско-Лужском междуречье // Научные исследования и музейные проекты МАЭ РАН в 2012 г. Радловский сборник. СПб.: МАЭ РАН, 2013. C. 21-27.

21. Герасимов Д.В., Холкина М.А. Археологическое изучение лагунных систем: исследования в Нарвско-Лужском междуречье в 2012-2014 гг. // Материалы полевых исследований МАЭ РАН. 2015. № 15. C. 243-259.

22. Kriiska A., Gerasimov D.V., Nordqvist K., Lisitsyn S.N., Sandell S. \& Kholkina M.A. Stone Age Research in the Narva-Luga Klint Bay Area in 2005-2014 // New sites, new methods. Iskos, 21, Helsinki: The Finnish antiquarian society, 2016. P. 101-115.

23. Kriiska A. New Neolithic settlements in Riigiküla // Proceedings of the Estonian Academy of Sciences. Humanities and Social Sciences. 1995. № 44 (4). P. 448-454.

24. Kriiska A. Archaeological excavations on the Neolithic site of Riigiküla IV // Proceedings of the Estonian Academy of Sciences. Humanities and Social Sciences. 1996. № 45 (4). P. 410-419.

25. Kriiska A. Corded Ware Culture sites in northeastern Estonia // De temporibus antiquissimis ad honorem Lembit Laanits. Muinasaja teadus, 8. Tallinn: Ajaloo Instituut, 2000. P. 59-79.

26. Kriiska A., Nordqvist K. Archaeological fieldwork at Stone Age settlement sites in Riigiküla, NorthEastern Estonia // Archaeological Fieldwork in Estonia 2006. Tallinn: Muinsuskaitseamet, 2007. P. 31-44.

27. Kriiska A., Rappu M. Riigiküla II asulakoha 2006.-2007. aasta arheoloogiliste päästekaevamiste tulemused // Maal, linnas ja linnuses. Uurimusi Narva piirkonna ajaloost. Narva Muuseumi toimetised, 8. Narva: Narva Muuseum, 2008. Lk. 8-45.

28. Гурина Н.Н. Новые неолитические памятники в восточной Эстонии // Древние поселения и городища. Таллинн: Eesti Riiklik Kirjastus, 1955. С. 153-175.

29. Salo U. Suomen esihistoriallinen menneisyys ja sen arkeologinen kuva lappalaiskulttuurin tarjoamien analogioiden valossa // Sanajalka. 1978. № 20. S. 5-16.

30. Jaanits L., Laul S., Lõugas V. \& Tõnisson E. Eesti esiajalugu. Tallinn: Eesti Raamat, 1982. $464 \mathrm{lk}$.

31. Thomson P.W. Narva diatomiit // Eesti Loodus. 1937. № 5. Lk. 214-216.

32. Лисицына Г.Н. Вопросы палеогеографии неолита районов северо-запада Европейской части СССР // Материалы и исследования по археологии СССР. 1961. Вып. 87. С. 535-578.

33. Долуханов П.М. История Балтики. М.: Наука, 1969. $118 \mathrm{c}$.

34. Lepland A., Hang T., Kihno K., Sakson M. \& Sandgren P. Holocene sea-level changes and environmental history in the Narva Area // Coastal Estonia. Recent Advances in Environmental and Cultural History. PACT 51. Rixensart: Council of Europe, 1996. P. 205-216.

35. Rosentau A., Muru M., Kriiska A., Subetto D., Vassiljev J., Hang T., Gerasimov D., Nordqvist K., Ludikova A., Lõugas L., Raig H., Kihno K., Aunap R. \& Letyka N. Stone Age settlement and Holocene shore displacement in the Narva-Luga Klint Bay area, eastern Gulf of Finland // Boreas, 2013. № 42:4. P. 912-931. 
36. Ryabchuk D.V., Sergeev A.Yu., Gerasimov D.V., Kriiska A., Nordqvist K., Budanov K.L.M., Kovaleva O.A., Zhamoida V.A., Anisimov M.A., Terekhov A.V. New data on the postglacial development of Narva-Luga Klint Bay (Eastern Gulf of Finland): results of geoarchaeological research // Journal of Coastal Conservation. 2018. P. 1-20. DOI: 10.1007/s11852-018-0670-5.

37. Indreko R. Kiviaja võrgujäänuste leid Narvas // Eesti Rahva Muuseumi Aastaraamat, VII. Tartu: Eesti Rahva Muuseum, 1932. Lk. 48-67.

38. Tõrv M., Meadows J. Radiocarbon dates and stable isotope data from the Early Bronze Age burials in Riigiküla I and Kivisaare settlement sites, Estonia // Radiocarbon. 2015. № 57 (4). P. 645-656.

39. Ермолова Н.М. О костных обрезках из костерезной мастерской неолитической стоянки Нарва I // Приложение к кн. Материалы и исследования по археологии СССР. Вып. 144. Л.: Наука, 1967. С. 199-205.

40. Полевые чертежи поселения Нарва I // Архив ИИМК РАН. Ф. 35 1951. Д. 75.

41. Kriiska A. Dwelling remains from Stone Age occupation sites in Estonia // Huts and houses. Stone Age and Early Metal buildings in Finland / ed H. Ranta. Helsinki: National Board of Antiquities, 2002. P. 235-239.

42. Tõrv M. Negative results and their contribution to the study of Estonian Prehistory // Zentrum für Baltische und Skandinavische Archäologie. Eine Forschungeseinrichtung der Stiftung Schleswig-Holsteinische Landmuseen Schloss Gottorf. Jahresbericht 2014. Schleswig: Zentrum für Baltische und Skandinavische Archäologie, 2015. P. 58-59.

43. Jussila T., Kriiska A. Shore displacement chronology of the Estonian Stone Age // Estonian Journal of Archaeology, 2004. № 8 (1). P. 3-32.

44. Lõugas L. Post-Glacial development of vertebrate fauna in Estonian water bodies: A palaeozoological study. Dissertationes Biologicae Universitatis Tartuensis, 32. PhD Thesis, Tartu University. 1997. $182 \mathrm{lk}$.

45. Lõugas L., Tomek T. Marginal effect at the coastal area of Tallinn Bay: the marine, terrestrial and avian fauna as a source of subsistence during the Late Neolithic // Man, his time, artefacts, and paces. Collection of articles dedicated to Richard Indreko. Muinasaja teadus, 19. Tartu: Tartu Ülikooli ajaloo ja arheoloogia instituut, 2013. P. 463-485.

\section{REVISION OF THE MATERIALS FROM THE RIIGIKÜLA I STONE AGE SETTLEMENT SITE (ESTONIA)}

(C) 2019

Khrustaleva Irina Yurievna, PhD student of Laboratory Archaeology, Chair of Laboratory Archaeology; junior researcher of Archaeology of Eastern Europe and Siberia Department University of Tartu (Tartu, Republic of Estonia),

State Hermitage Museum (Saint Petersburg, Russian Federation)

Kriiska Aivar, PhD, professor of Laboratory Archaeology, Chair of Laboratory Archaeology

University of Tartu (Tartu, Republic of Estonia)

Kholkina Margarita Alekseevna, candidate of historical sciences,

senior lecturer of Archeology Department; engineer of Regional Geoecology and Marine Geology Department Saint Petersburg State University (Saint Petersburg, Russian Federation);

A.P. Karpinsky Russian Geological Research Institute (Saint Petersburg, Russian Federation)

Abstract. The Riigiküla I settlement site in northeast Estonia, which was found and excavated at the beginning of $1950 \mathrm{~s}$, is an important source of information about the life and households of the Stone Age population in the Eastern Baltic and one of the few settlement sites in Estonia that includes the remains of dwellings. Besides two pit-houses, a few fireplaces, two entire human skeletons and the disarticulated bones of at least three more individuals, as well as a rich inventory comprised of pottery fragments, tools and waste from the production of quartz, bone, antler, flint, etc., were discovered here. At first, the site was interpreted as a single long-term dwelling site. Nevertheless, the discovery of new data at other sites in the region, as well as a partial re-analysis of the pottery and new AMS dates obtained from the human bones, indicated the necessity to revise all the materials. The preliminary results of this work are 
presented in our paper. It was established that at least four buildings correlated to Narva and Comb Ware cultures existed on the settlement site, indicating that, at least partially, they existed at different times. Find materials in the occupation layer are obviously mixed vertically because of the existence of multi-temporal settlement sites in this area, but they are also clearly correlated to objects horizontally. For a while, this place was apparently visited by the representatives of the Corded Ware culture (judging by the few fragments of pottery). And in the middle of the Bronze Age, people buried their dead here.

Keywords: Stone Age; Bronze Age; coast of Baltic Sea; northeast Estonia; basin of Narva River; Stone Age settlement site; multilayer settlement site; Comb Ware culture; Narva culture; pit-houses; remains of dwellings; fireplaces; Bronze Age burials; stratigraphy; spatial analysis.

УДК 902.64; 903.23

DOI 10.24411/2309-4370-2019-12223

Статья поступила в редакцию 06.02.2019

\section{НЕОЛИТИЧЕСКИЕ КОМПЛЕКСЫ КОКШАРОВСКОГО ХОЛМА: ГЕНЕЗИС, ЭТАПЫ РАЗВИТИЯ И КУЛЬТУРНАЯ ПРЕЕМСТВЕННОСТЬ}

(C) 2019

Шорин Александр Фёдорович, доктор исторических наук, главный научный сотрудник сектора археологии каменного века

Шорина Анастасия Александровна, младший научный сотрудник сектора археологии каменного века Институт истории и археологии УрО РАН (2. Екатеринбург, Российская Федераиия)

Аннотация. В статье анализируются вопросы эволюции и культурной преемственности неолитических комплексов памятника археологии «Кокшаровский холм - Юрьинское поселение». Основанием для решения этих вопросов служит присутствие в культурных слоях памятника всех типов неолитической керамики зауральского региона: кошкинской, кокшаровско-юрьинской (козловской), полуденской, басьяновской (боборыкинской). Каждый из них имеет достоверную временную привязку, базирующуюся как на стратиграфических наблюдениях, так и на солидной, 54 определения, базе радиоуглеродных дат. Начало неолитической эпохи на памятнике связано с формированием не позднее третьей - последней четверти VII тыс. до н.э. комплексов кошкинского типа, одновременно с которыми или чуть позже, но не позднее самого начала VI тыс. до н.э., появляются кокшаровско-юрьинские комплексы. В оформлении керамической посуды обеих этих культур доминирует отступаюше-накольчатая техника орнаментации. Но в орнаментации кокшаровско-юрьинской посуды больше черт, восходящих к местной ее мезолитической основе. Отличительной особенностью обеих культур является также наличие посуды с рельефными налепами. Население этих культур существовало, нередко в рамках экзогамных коллективов, на протяжении раннего этапа неолита региона, до рубежа VI-V, а то и первой четверти $\mathrm{V}$ тыс. до н.э., когда происходит их переоформление в поздненеолитическое полуденское и басьяновское. Радиоуглеродные даты, полученные по фрагментам керамики аятской культуры, укладывающиеся в интервал третьей - последней четверти V тыс. до н.э., маркируют начало энеолитической эпохи на памятнике.

Ключевые слова: неолит; Среднее Зауралье; керамическое производство; типология; орнаментация; керамическая традиция; культовые комплексы; кошкинская культура; кокшаровско-юрьинская (козловская) культура; полуденская культура; басьяновский тип боборыкинской культуры; генезис; культурная преемственность.

Присутствие на Кокшаровском холме всех типов неолитической керамики региона: кошкинской, кокшаровско-юрьинской (козловской), полуденской, басьяновской (боборыкинской), а также наличие 54 радиоуглеродных дат, полученных по разным основаниям (уголь, керамика) и достоверно определяющих хронологические позиции каждого из этих культурных комплексов, делают памятник эталонным для решения вопросов эволюции и культурной преемственности этих комплексов на протяжении всей эпохи неолита Зауралья $[1 ; 2$, с. 89-91; 3; 4]. Хронологическое соотношение данных комплексов коррелируется и стратиграфией объекта 21 (жилища) Юрьинского поселения (рис. 1), в центре которого этот насыпной святилищный комплекс и был возведен теми же группами неолитического населения.

Начало неолитической эпохи как на памятнике, так и в зауральском регионе в целом относится к рубежу VII-VI тыс. до н.э. и, может, даже третьей - последней четверти VII тыс. до н.э. в калиброванных значениях дат [4, с. 99-103]. Оно связано с комплексом кошкинского типа (рис. 2: 1, 2, 4, 8). Установить генетические истоки этого комплекса не только на Холме, но и в регионе в целом современными археологическими методиками практически невозможно.
Керамическая традиция выглядит сформировавшейся, и идентичные культурные комплексы на сопредельных Зауралью регионах отсутствуют. Можно только констатировать, а это делалось неоднократно разными исследователями, что кошкинский керамический комплекс относится к кругу культур с накольчатой традицией орнаментации, больше свойственной культурам степных восточноевропейских регионов [5, с. $35,37,61-62 ; 6$, с. 109,113$]$. Присуще ему также «шамотная» традиция и высокая доля отбора исходного пластичного сырья без талька [7, c. 109-110, 122], что не свойственно населению, изготавливавшему керамику кокшаровско-юрьинского типа, одновременному на Холме кошкинскому. Но этот керамический импульс, пусть даже изначально пришлый в зауральский регион, местным населением был не только воспринят, но и основательно переработан. На это указывают как оригинальность самой кошкинской орнаментальной композиции, не имеющей аналогов в других регионах Евразии, так и наличие в тесте сосудов примеси не столько шамота, сколько талька, иногда в значительных количествах; технологической традиции, свойственной на всем протяжении существования лепной посуды гончарам именно зауральского региона. 